\title{
The time-varying effects of oil prices on oil- gas stock returns of the fragile five countries
}

Begüm Yurteri Kösedağlı, Gül Huyugüzel Kışla* (10 and A. Nazif Çatık

*Correspondence: gul.kisla@ege.edu.tr Ege Universitesi, Izmir, Turkey

\begin{abstract}
This study analyzes oil price exposure of the oil-gas sector stock returns for the fragile five countries based on a multi-factor asset pricing model using daily data from 29 May 1996 to 27 January 2020. The endogenous structural break test suggests the presence of serious parameter instabilities due to fluctuations in the oil and stock markets over the period under study. Moreover, the time-varying estimates indicate that the oil-gas sectors of these countries are riskier than the overall stock market. The results further suggest that, except for Indonesia, oil prices have a positive impact on the sectoral returns of all markets, whereas the impact of the exchange rates on the oil-gas sector returns varies across time and countries.
\end{abstract}

Keywords: Sectoral stock return, Oil price, Time-varying parameter model, Fragile five JEL Classification: G12, C5, C58

\section{Introduction}

Despite the increasing share of natural gas and renewables, oil remains the most widely used primary energy source, comprising 33.1 percent of global primary energy consumption as of 2019 (BP 2020). Due to its importance, a plethora of studies have been conducted to uncover the effects of oil price fluctuations on major macroeconomic and financial variables including stock markets. As indicated by Arouri and Rault (2011), oil price fluctuations may play a crucial role in determining stock returns through their influence on macroeconomic events. A change in the macroeconomic environment may further trigger a change in the discounted cash flows used to calculate the market value of stock.

While an abundance of empirical works has been conducted after the seminal studies of Jones and Kaul (1996) and Huang et al. (1996), no consensus has yet emerged about the significance of the effect of oil price fluctuations on the stock market. ${ }^{1}$ Some studies reported evidence of the significant impact of oil prices (Park and Ratti 2008), whereas others have found weak effects of oil price shocks on stock returns (Huang et al. 1996; Hammoudeh and Choi 2006; Apergis and Miller 2009). Some studies also found that the significance of the impact of oil prices varies across the estimation sample in terms of either time periods (Lee and Zeng 2011; Miller and Rati 2009), countries (Jones and Kaul

\footnotetext{
${ }^{1}$ The empirical findings of the selected studies are presented in Table 4 of the "Appendix".
}

(c) The Author(s) 2021. Open Access This article is licensed under a Creative Commons Attribution 4.0 International License, which permits use, sharing, adaptation, distribution and reproduction in any medium or format, as long as you give appropriate credit to the original author(s) and the source, provide a link to the Creative Commons licence, and indicate if changes were made. The images or other third party material in this article are included in the article's Creative Commons licence, unless indicated otherwise in a credit line to the material. If material is not included in the article's Creative Commons licence and your intended use is not permitted by statutory regulation or exceeds the permitted use, you will need to obtain permission directly from the copyright holder. To view a copy of this licence, visit http:// creativecommons.org/licenses/by/4.0/. 
1996; Nandha and Hammoudeh 2007; Arouri and Rault 2011; Wang et al. 2013), or the nature of the oil shock (Kilian and Park 2009; Kang et al. 2016).

Recent studies have struggled to explain the differences in the empirical evidence for several reasons. Some studies have focused on the possible nonlinearity in the relationship due to fluctuations in the oil and stock markets (Ciner 2001; Zhu et al. 2011; Broadstock et al. 2012; Huang et al. 2017; Aloui et al. 2012; Jimenez- Rodriguez 2015; Joo and Park; 2017; Jebran et al. 2017; Roubaud and Arouri 2018). Ciner (2001) investigates the dynamic linkages by using nonlinear Granger causality and finds a feedback relationship between oil prices and US stock returns. Similar results are also reported by Zhu et al. (2011), who find a bidirectional positive long-run relationship between oil prices and stock prices for 14 OECD and non-OECD countries. Using time varying conditional correlation and asset pricing models, Broadstock et al. (2012) analyze the relationship between international oil price and energy related stock returns for the Chinese stock market and find that the relationship strengthened after the 2008 global financial crisis (GFC). On the other hand, Huang et al. (2017) find no asymmetric impact of oil prices on stock returns on the Chinese stock market by using a Value-at-Risk model composed of wavelet transformed variables. Classifying a group of 25 emerging markets into three sub-samples based on their oil dependency, Aloui et al. (2012) report that the oil sensitivity of stock returns is asymmetric, being more sensitive to up periods than down periods in the global oil market. They also find that exchange rate is another important risk factor in emerging markets whose stock returns are positively correlated with oil price changes. Rodríguez (2015) investigates the nonlinear relationship between real oil prices and real stock returns through the VAR model for developed countries. The study shows that an increase in oil price has a negative and statistically significant impact on stock returns for all countries. Joo and Park (2017) provide supportive evidence for the negative and significant time-varying effects of oil price uncertainty on stock returns for US, Japan, South Korea, and Hong Kong. Jebran et al. (2017) find evidence of the asymmetric effects of oil price shocks on Pakistan's stock returns, that is, oil price shocks have an adverse effect on the stock market before the GFC period in contrast to the positive effects obtained post-crisis. Roubaud and Aoruri (2018) find a nonlinear relationship between oil prices, US dollar exchange rates, and the stock markets; this relationship is stronger during high volatility regimes mostly associated with the recession periods of the US economy.

Apart from the nonlinearity in the relationship, some studies have also asserted that the effects of oil prices on stock returns should be investigated at a sectoral level since the estimates utilizing aggregate stock returns are based on the improbable assumption that all sectors are identically affected by oil price shocks (Sadorsky 2001; El-Sharif et al. 2005; Sanusi and Ahmad 2016; Nandha and Faff 2008; McSweeney and Worthington 2008; Gogineni 2010; Narayan and Sharma 2011; Arouri and Nguyen 2010; Elyasiani et al. 2011, 2013; Moya-Martínez et al. 2014; Inchauspe et al; 2015; Uzo-Peters et al. 2018). In a seminal paper, Sadorsky (2001) finds that oil prices have a positive and significant impact whereas exchange rate fluctuations have an adverse impact on Canadian oil and natural gas returns. Using multi-factor asset pricing models, El-Sharif et al. (2005) and Sanusi and Ahmad (2016) find that oil prices have a positive significant effect on the oil and natural gas stock returns in the United Kingdom. Nandha and Faff 
(2008) investigate the effect of oil price shocks on stock market returns at a global level for 35 industries and find that oil price shocks have a negative impact on equity returns from all industries except mining and oil and gas. On the other hand, McSweeney and Worthington (2008) report a strong positive correlation between oil price and energy industry returns for Australia while the banking, retail, and transportation industries are negatively affected by oil price shocks. Focusing on US firms, Gogineni (2010) and Narayan and Sharma (2011) find that firm size and the industry's oil dependency are important indicators to determine the exposure to oil price shocks. Arouri and Nguyen (2010) use the multi-factor asset pricing model and the Granger causality test for 12 European countries at the sectoral level, and report a strong and significant correlation between oil price changes and stock exchanges in most European countries. However, the structure and sensitivity of stock returns to oil price shocks varies significantly across industries, with the oil-gas industry showing a high positive sensitivity to oil prices in contrast to the food and beverages industry, which shows a negative sensitivity to oil prices. Using industrial level data, Elyasiani et al. (2011) find that oil price fluctuations create systematic risks in US asset prices. The results obtained through the Generalized Autoregressive Conditionally Heteroscedastic $(\mathrm{GARCH})$ model also show that the volatility of the oil industry excess returns has a long memory and varies over time. Elyasiani et al. (2013) investigate the effects of oil price shocks on basic manufacturing and financial industry stock returns in the US economy. Using a Double-Threshold Fractionally Integrated Generalized AutoRegressive Conditionally Heteroskedastic (FIGARCH) model, they find that oil price shocks have a less important effect on stock returns in periods associated with lower volatility in the oil market. Moya-Martinez et al. (2014) use a multi-factor model that allows multiple structural changes in the parameters and find that the impact of oil price changes on the Spanish stock market is quite modest and oil price shocks have a stronger impact on industries with a higher degree of oil price exposure. They also report that the oil price sensitivity of the Spanish stock market has increased in the 2000s compared to the 1990s. Inchauspe et al. (2015) use a statespace multi-factor asset pricing model to assess the impact of oil prices on the returns of renewable energy firms; they find that the effects of oil prices have weakened after 2005. On the other hand, Uzo-Peters et al. (2018) find that oil price shocks have a significant negative effect on oil industry stock returns of Nigeria, which is a developing oil exporter country.

Given the literature outlined above, the main objective of the present study is to contribute to the literature by first investigating the effects of oil prices on the oil-gas sector stock returns of the fragile five markets as originally classified by Morgan Stanley in 2013, namely Brazil, India, Indonesia, South Africa, and Turkey. Owing to data limitations associated with the newer fragile five inclusions (Mexico and Columbia), the more recently updated fragile five countries cannot be studied at this point. Nonetheless, fragile five countries present an interesting case to analyze the effects of oil shocks on the oil-gas sector for several reasons. First, as indicated by previous studies (Ramos and Veiga 2011), unlike in the other sectors, fluctuations in oil prices have direct consequences on the stock returns of the oil-gas sector since oil is utilized as the primary 
input in the production process. ${ }^{2}$ The oil-gas sector also has strong linkages with many industries, especially transportation, automobile, chemicals, and manufacturing as petroleum products are widely used as the key material in those industries. Second, fragile five countries differ in terms of the size of their oil-gas sectors and trade positions. ${ }^{3}$ For instance Brazil is an important country in the oil-gas market, accounting for more than 3.5 percent of world natural gas liquids (NGL) production; besides, the country is also an important exporter in the oil and NGL market with a 2.3 percent share of total crude oil and NGL exports in 2017. India is a net exporter of oil products, accounting for 4.8 percent of total world oil products exports. On the other hand, it is also one of the largest crude oil and natural gas importers, constituting 9.1 percent of the global import as of 2017. Among the fragile five countries, Brazil and Indonesia are net exporters, while India, South Africa and Turkey are considered net importers of natural gas and oil. Third, fragile five countries have relatively weak macroeconomic and financial structures as evidenced by the crises they experienced over the last three decades. ${ }^{4}$ Hence, one can expect that external shocks due to fluctuations in global oil prices may have more serious implications on the financial system of these countries including their oil-gas sectors (Nasir et al. 2018; Maghyereh 2004). Therefore, it is crucial to focus on the fragile five countries. As far as we know, this is the first study considering the effect of the oil price exposure on the oil-gas sector stock returns in the fragile five countries.

In order to assess the effects of such fluctuations on the countries' oil-gas sector, we attempt to take into account possible time-varying dynamics in asset-pricing behavior. Among the alternative methodologies in the literature, that is, regime-switching GARCH or Markov regime-switching models, we utilize the time-varying parameter state-space model based on the Kalman filter (Kalman 1960), as the coefficients derived from this model are better able to track the evolution in the risk factors affecting the oilgas sector of the countries. ${ }^{5}$ The use of time-varying disturbance terms of the measurement and state equations also enables us to evaluate the impact of abrupt changes in the magnitude of the shocks, similar to the GARCH model.

The rest of this study is structured as follows. This study's methodology and data are described in the next section. "Empirical results" section lists the empirical findings of the study based on the asset pricing model estimated for the oil-gas sector. Finally, the study ends with concluding remarks and policy proposals in light of the empirical findings.

\footnotetext{
${ }^{2}$ In order to further justify the selection of the oil-gas sector of the fragile five countries, we also plot rolling window correlations between oil prices and selected major sectors (i.e., basic materials and financials and industrials) and compare them with that of the oil-gas sector (see Fig. 4). Following Aloui et al. (2012), the window size of the correlation is set to 750 days because a longer period may yield statistically more reliable results. As can be seen, except for Indonesia, the oil price correlations of other sectors are lower than that of the oil-gas sector for all countries over the majority of the analysis period. It is also noteworthy that the lower correlation between oil prices and the oil-gas sector in Indonesia is also in line with the time-varying oil price parameter estimates.

3 Country-level data on oil and natural gas production and trade are presented in Table 5 of the "Appendix".

${ }^{4}$ Macroeconomic and financial indicators, GDP growth, inflation, current account balance, and net portfolio investments of the countries are presented in Fig. 5, 6, 7 and 8 of the "Appendix". It is notable that the countries do not have a stable growth path and are seriously affected by local and global economic crises, though high growth rates are achieved in some periods. Among the countries analyzed, Brazil, Indonesia, and Turkey had very high inflation rates in the 1990s, whereas India and South Africa experienced double-digit inflation rates in the crisis periods. Current account deficits experienced during the period reflect the countries' reliance on foreign investment to sustain their economic growth, whereas the fluctuations in net portfolio investments may indicate higher exposure to risks in financial markets.

${ }^{5}$ Choudhry and Wu (2008) have shown that the time-varying state-space model performs better in terms of forecasting accuracy than the alternative GARCH specifications.
} 


\section{Methodology and data \\ Methodology}

To analyze the risk factors affecting the oil-gas stock returns of the fragile five countries, this study utilizes a capital asset pricing model (CAPM) inspired from Markowitz's (1959) portfolio choice model. Introduced by Sharpe (1964) and Lintner (1965), the CAPM has been widely used in finance literature to measure the market risk of a particular equity. It can be formulated as follows:

$$
R_{i t-} R_{f t=} \alpha_{i}+\beta_{i M}\left(R_{M t}-R_{f t}\right)+\varepsilon_{i t}
$$

where $R_{i t}$ represents the return on asset $i, R_{f t}$ is the risk-free interest rate and $R_{M t}$ isthemarketreturn. In this setting, an asset's excess return $\left(R_{i t}-R_{f t}\right)$ is explained by its expected CAPM risk premium $\left(\beta_{i M}\left(R_{M t}-R_{f t}\right)\right)$. The intercept coefficient, $\alpha_{i}$, is known as "Jensen's alpha" and is set to be equal to zero for each asset (Jensen 1968).

Asset pricing models augmented with other risk factors are called multi-factor asset pricing models; such models have been widely used to analyze the importance of other risk factors in affecting excess stock returns (Karlsson and Hacker 2013; Wen et al. 2019). In this study, we employ the following multi-factor asset pricing model including the excess returns of oil prices and exchange rates based on Sadorsky (2001), El-Sharif et al. (2005), Nandha and Faff (2008), McSweeney and Worthington (2008), and MoyaMartinez et al. (2014)

$$
\text { Roilgas }_{t}=\alpha_{0}+\beta_{m} \operatorname{Rm}_{t}+\beta_{\text {oil }} \text { Roil }_{t}+\beta_{\text {er }} \text { Rer }_{t}+u_{i t}
$$

where Roilgas ${ }_{t}$ stands for excess return in the oil-gas sector at time $t ; \operatorname{Rm}_{t}, \operatorname{Roil}_{t}$ and $\operatorname{Rer}_{t}$ represents the excess returns on market, oil prices, and exchange rates, respectively, at time $t$. In this equation, $\beta_{m}$ parameter, also known as market beta, measures the market risk of the oil-gas sector. The parameters $\beta_{o i l}$ and $\beta_{e r}$ reflect the impact of oil prices and exchange rate returns on the oil-gas sector, respectively.

In order to analyze the impact of oil prices on the oil-gas sector returns in the fragile five countries within a time-varying framework, the linear model in Eq. (2) is rewritten in the state-space form:

$$
\begin{aligned}
& \text { Roilgas }_{i t}=\alpha_{0, t}+\beta_{m, t} \operatorname{Rm}_{t}+\beta_{o i l, t} \operatorname{Roil}_{t}+\beta_{e r, t} \operatorname{Rer}_{t}+u_{i t} \quad \mu_{i t} \sim i i d\left(0, \sigma_{\mu, t}^{2}\right) \\
& \alpha_{0, t}=\alpha_{0 . t-1}+v_{\alpha . t} \quad v_{\alpha . t} \sim \operatorname{iid}\left(0, \sigma_{v \alpha . t}^{2}\right) \\
& \beta_{m . t}=\beta_{m . t-1}+v_{m . t} \quad v_{m . t} \sim i i d\left(0, \sigma_{v m . t}^{2}\right) \\
& \beta_{\text {oil.t }}=\beta_{\text {oil.t-1 }}+v_{\text {oil.t. }} \quad v_{\text {oil.t }} \sim \text { iid }\left(0, \sigma_{\text {voil.t. }}^{2}\right) \\
& \beta_{\text {er.t }}=\beta_{\text {er.t-1}}+v_{\text {er.t }} \quad v_{\text {er.t }} \sim \operatorname{iid}\left(0, \sigma_{\text {ver.t }}^{2}\right)
\end{aligned}
$$


Equation (3) is the measurement equation while Eqs. (4)-(7) are used to model timevariation in the coefficients and are known as transition equations. Aligned with recent studies, such as Inchauspe et al (2015), Moya-Martinez et al. (2014), and Karlson and Hacker (2013), this study assumes that the coefficients vary over time by following a random walk without intercept process. It is further presumed that the disturbances of the state equations are independently and identically distributed with zero mean and constant variance.

The model described above is estimated with maximum likelihood through the Kalman filter (Kalman 1960) following three steps: prediction, updating, and smoothing. ${ }^{6}$ The optimal predicted value of the oil-gas stock returns, Roilgas $_{t}$, is determined based on available information at time $t-1$ in the prediction step. Then, the estimated coefficients in the prediction step are updated using the prediction error obtained by comparing the actual and predicted values of the dependent variable. The state variables obtained from the updating stage utilizes past information and the current values of the dependent variable. Finally, the estimation process ends with the smoothing step in which the smoothed time-varying parameter estimates are computed through the available information using the whole sample.

\section{Data description}

This study analyzes the factors affecting oil-gas sector returns of the fragile five countries based on daily data from 29 May 1996 to 27 January 2020 obtained from the Thomson Reuters Datastream. ${ }^{7}$ Daily spot prices of Brent crude oil in US dollars per barrel is selected as the global price of oil. Along with oil prices, the exchange rate, defined as the units of national currency per US dollar, is introduced as an additional risk factor since oil is traded in US dollars in the market (Zhang et al. 2008; Roubaud and Arouri 2018). As a measure of market risk, we prefer the national (benchmark) stock market returns.

As explained in the methodology section, asset pricing models measure the risk of the factors affecting stock price relative to the risk-free rate of returns; hence, excess return of the oil-gas sectors over market returns and oil and exchange rate variables are calculated by taking the difference between the daily values on deposit overnight rates from the daily $\log$ returns of each of these variables.

Table 1 presents the descriptive statistics, unit root tests, and correlations of the variables with the exchange rates and oil prices. The returns of all the countries have positive means and similar magnitudes. The highest volatility is observed in the stock return of Indonesia (0.06) whereas the lowest volatility is reported in the stock return of India (0.02). It is also notable that Indian, Indonesian, and South African stock returns exhibit negative skewness with excess kurtosis. This negative skewness can generally be observed in the crisis periods including the 1997 Asian crisis, 1998 Russian financial crisis, 19992002 Argentine economic crisis, 1999 Samba effect, 2000-2002 dotcom bubble, 2001 Turkish economic crisis, 2008 GFC (or US mortgage crisis), and the latest European debt crisis of 2010-2012. Also, Jarque-Bera tests implying the non-normality of individual

\footnotetext{
${ }^{6}$ The detailed estimation steps of Kalman filtering can be found in Kim and Nelson (1999) and Commandeur and Koopman (2007)

7 Due to unavailability of the oil and gas sector stock prices of new fragile five countries, that is, Mexico and Colombia, our study is focused on the first list of "Fragile Five" countries classified by Morgan Stanley (2013).
} 


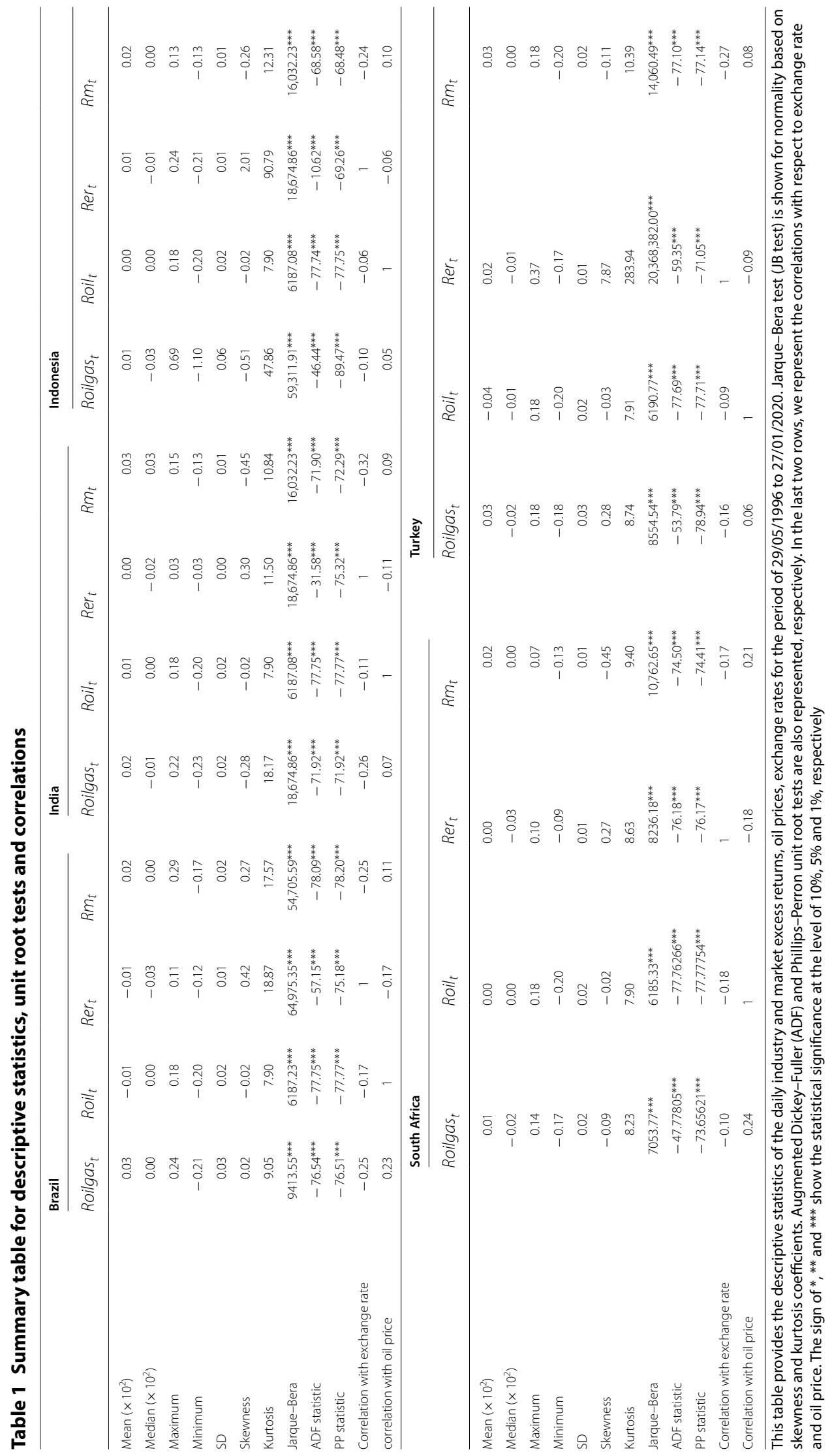


Table 2 OLS Estimation and Bai-Perron Structural Break Test Results (with endogenous structural breaks)

\begin{tabular}{|c|c|c|c|c|c|c|}
\hline Countries & Break point & $\alpha_{0, t}$ & $\beta_{m, t}$ & $\beta_{e r, t}$ & $\beta_{\text {oil,t }}$ & $\mathrm{R}^{2}$ \\
\hline \multicolumn{7}{|c|}{ OLS estimation } \\
\hline \multicolumn{2}{|l|}{ Brazil } & 0.000126 & $0.875460^{* * *}$ & $-0.146177^{* * *}$ & $0.158842^{* * * *}$ & 0.52 \\
\hline \multicolumn{2}{|l|}{ India } & 0.0000726 & $0.825930 * * *$ & $-0.243390^{* * *}$ & 0.006493 & 0.45 \\
\hline \multicolumn{2}{|l|}{ Indonesia } & -0.0000999 & $1.075279^{* * *}$ & -0.137160 & $0.066054^{*}$ & 0.07 \\
\hline \multicolumn{2}{|l|}{ South Africa } & -0.00004995 & $1.138391^{* * *}$ & $0.068018^{* * *}$ & $0.107052^{* * *}$ & 0.42 \\
\hline \multicolumn{2}{|l|}{ Turkey } & -0.0000309 & $0.932650^{* * *}$ & $0.126296^{* * *}$ & 0.008531 & 0.58 \\
\hline \multicolumn{7}{|c|}{ Structural break test } \\
\hline \multirow[t]{4}{*}{ Brazil } & 5/29/1996-2/18/2005 & $0.000603^{* *}$ & $0.642222^{* * *}$ & -0.116007 & $0.072183^{* * *}$ & 0.5 \\
\hline & $2 / 21 / 2005-10 / 29 / 2008$ & 0.000413 & $0.986934^{* * *}$ & $0.222943^{* * *}$ & $0.254153^{* * *}$ & \\
\hline & 10/30/2008-10/25/2013 & $-0.000586^{* *}$ & $1.053020^{* * *}$ & -0.061483 & $0.062233^{*}$ & \\
\hline & 10/28/2013-1/27/2020 & -0.000343 & $1.639746^{* * *}$ & -0.016847 & $0.247443^{* *}$ & 9 \\
\hline \multirow[t]{2}{*}{ India } & 5/29/1996-7/23/2001 & -0.000514 & $0.521387^{* * *}$ & -0.035074 & 0.007515 & 0.48 \\
\hline & $7 / 24 / 2001-1 / 27 / 2020$ & -0.0000511 & $1.007997^{* * *}$ & -0.037511 & -0.002632 & \\
\hline \multirow[t]{2}{*}{ Indonesia } & 5/29/1996-6/11/2013 & -0.000117 & $1.122839^{* * *}$ & $-0.130678^{* *}$ & $0.073500^{*}$ & 0.07 \\
\hline & $6 / 12 / 2013-1 / 27 / 2020$ & -0.00000672 & $0.681139 * * *$ & $-0.223451^{* *}$ & $0.040255^{* *}$ & \\
\hline \multirow[t]{5}{*}{ South Africa } & $5 / 29 / 1996-5 / 02 / 2000$ & -0.000233 & $1.334895^{* * *}$ & -0.014336 & -0.020979 & 0.44 \\
\hline & $5 / 03 / 2000-5 / 04 / 2004$ & 0.000711 & $0.806143^{* * *}$ & $0.211758^{* * *}$ & $0.091385^{* * *}$ & \\
\hline & $5 / 05 / 2004-2 / 27 / 2009$ & 0.000349 & $1.136216^{* * *}$ & 0.029423 & $0.159178^{* * *}$ & \\
\hline & 3/02/2009-8/19/2014 & -0.000149 & $1.054967^{* * *}$ & -0.033209 & $0.046801^{* * *}$ & \\
\hline & $8 / 20 / 2014-1 / 27 / 2020$ & -0.000596 & $1.157973^{* * *}$ & $0.255591^{* * *}$ & $0.226009^{* * *}$ & \\
\hline \multirow[t]{3}{*}{ Turkey } & 5/29/1996-12/24/1999 & 0.000927 & $1.053471^{* * *}$ & -0.021754 & 0.050071 & 0.58 \\
\hline & 12/27/1999-7/30/2003 & -0.000743 & $0.904620^{* * *}$ & $0.128122^{* * *}$ & $-0.059603^{* *}$ & \\
\hline & $7 / 31 / 2003-1 / 27 / 2020$ & -0.0000776 & $0.825581^{* * *}$ & 0.032943 & $0.025070^{* * *}$ & \\
\hline
\end{tabular}

This table have two estimation results; it reports the OLS regression results of the multi-factor linear model and the Bai-Perron structural break estimates with the break points. Standard errors of the estimated coefficients are corrected for autocorrelation and heteroscedasticity with the Newey-West procedure. The sign of *,** and ${ }^{* * *}$ show the statistical significance at the level of $10 \%, 5 \%$ and $1 \%$, respectively

oil price, exchange rates, and stock returns support this assessment. According to Augmented Dickey-Fuller (ADF) and Phillips-Perron unit tests, all the variables are found to be stationary at the $1 \%$ level of significance. Lastly, each of exchange rates and oil prices has a low correlation with the other variables.

\section{Empirical results}

In this section, first, a linear asset-pricing model is estimated. The results presented in Table 2 indicate that the oil-gas sectors' sensitivities to the risk factors, namely market, oil price, and exchange rates, differ across the countries. The estimated market return coefficients are positive and significant for all countries whereas the effects of exchange rate returns differ across the countries. In particular, the oil-gas sectors of Brazil and India are affected negatively by exchange rate fluctuations whereas exchange rate has a positive effect on the oil-gas sectors of South Africa and Turkey. A positive and significant impact of oil price returns is reported for each of Brazil, Indonesia, and South Africa.

Second, the stability of the asset-pricing models is investigated throughBai and Perron's $(1998,2003)$ multiple structural break tests. This test has an advantage over its possible alternatives since it allows for endogenous detection of timing and the number of 
structural breaks. ${ }^{8}$ The results presented in Table 2 indicate the presence of at least one statistically significant structural breakpoint for all asset-pricing models of the countries. In particular, the highest number of breakpoints is obtained for South Africa at five breaks and the lowest number of breakpoints is found for India and Indonesia. Some of these breakpoints can be related to major political or economic events. For example, the breakpoints of Brazil are consistent with the 2008 GFC and the 2014-2017 Brazilian economic crisis. On the other hand, the structural breakpoints of India and Indonesia appear to be quite independent from global crises periods. Specifically, there were political issues between India and Pakistan in 2001. For Turkey, 1999-2003 includes periods of macroeconomic and political instabilities such as the 2000 and 2001 economic crises, IMF Stabilization program, and natural disasters including the 1999 earthquake.

The coefficient of market return is reported as positive and significant for all countries. On the other hand, the effect of exchange rates differs across countries. Specifically, positive and significant coefficients are observed for Brazil, South Africa, and Turkey in contrast to Indonesia. Finally, except for India, positive and significant coefficients of oil price returns are obtained for all countries. For Turkey, while a negative and significant oil price effect is observed between 1999 and 2003, the corresponding coefficient is positive and significant between 2003 and 2020. Overall, the variation in the coefficients of the oil price and the exchange rate returns across the regimes supports the use of the time-varying approach (see Table 2).

Third, after checking for structural breaks, a time-varying parameter model, presented in Eqs. (4)-(7), is estimated to analyze the risk factors affecting the oil-gas sector returns of each country. The model is also estimated by including up to five period lags of oil price and exchange rate returns to capture possible time-lags in the relationship (McSweeney and Worthington 2008; Gogineni 2010; Narayan and Sharma 2011; MoyaMartinez et al. 2014).

The time-varying coefficients of the market returns of the fragile five countries are plotted inFig. 1 . The results suggest that the variations in market risk are mostly associated with the various financial crises and fluctuations in oil prices. Brazil has the riskiest oil-gas sector as the market beta has risen above unity in early 2011 and peaked at 1.853 in April 2015. Since then, the market risk has declined gradually, associated with the decline in oil prices in the world market. ${ }^{9}$ Indonesia has the second riskiest oil-gas sector with a maximum market beta coefficient of 1.837 on 27 October 1999. This may be associated with the Asian financial crisis experienced around that time. Market risk also rose above unity over the periods 2003-2004 and 2008-2012 due to the possible impact of the GFC. In contrast, the market risk coefficients of India, South Africa, and Turkey followed a relatively stable pattern. Turkey seems to have the least risky oil-gas market with a mean coefficient of 0.873 and a range of $0.75-1.219$, whereas the time-varying market beta values for the South African oil-gas stock returns were estimated to be generally above unity.

The time-varying coefficient estimates of oil price and exchange rate returns for each country are illustrated in Figs. 2 and 3, respectively. These figures illustrate

\footnotetext{
${ }^{8}$ The number of breaks in the asset pricing models is determined as follows based on Bai and Perron (2003): First, a double maximum test is used to detect the presence of any structural break. Next, the optimum number of breaks is determined with the $\operatorname{supF}_{t}(1+1 \mid l)$ test and information criterions suggested by Liu et al. (1997).

${ }^{9}$ In that time, crude oil spot prices plateaued at around US\$110 per barrel between March 2011 and June 2014, and declined thereafter to hit \$25 per barrel in early 2016.
} 

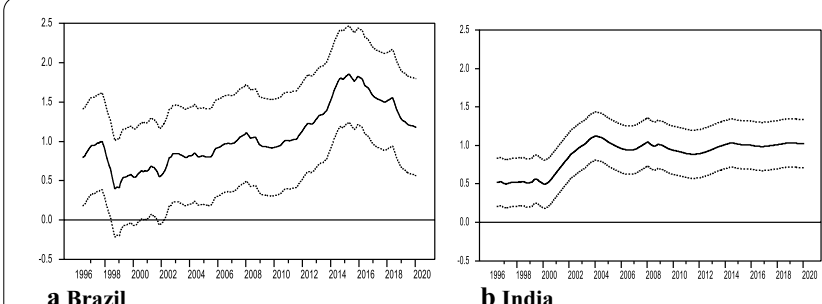

a Brazil

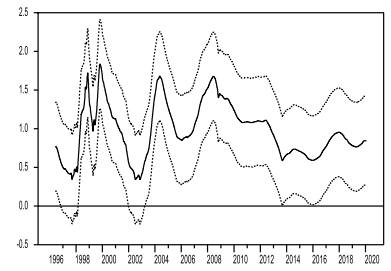

c Indonesia

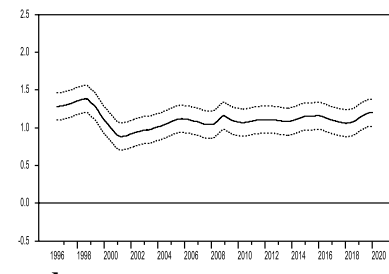

d South Africa

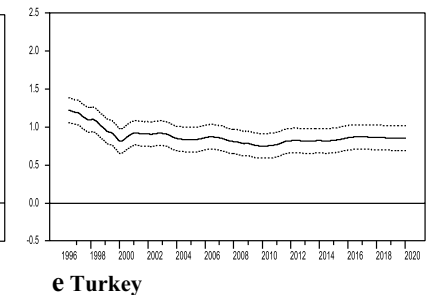

Fig. 1 Market return coefficients

contemporaneous as well as the cumulative sum of the parameters for up to three and five lags. Regarding the time-varying parameters of oil price returns, we find mostly positive parameter estimates for all countries except Indonesia. The largest impact of oil prices is obtained for South Africa with a mean coefficient of 0.227 and a range of -0.002 (07 June 1996) and 0.384 (17 January 2020; see Fig. 3 and Table 3). This is followed by Brazil with a mean coefficient of 0.163 and range between -0.052 (13 November 1997) and 0.327 (01 November 2017). The impacts of oil prices are found to be minimal for the remaining countries. Cumulative effects of oil prices are generally positive for Turkey and follow a relatively stable pattern with a mean of 0.0054, ranging between -0.114 and 0.167 . Positive and significant effects of oil prices are reported from around the middle of 2006 till the end of 2013. On the other hand, India's oil-gas sector stock returns seem to be least responsive to changes in oil price returns.

In contrast to the evidence on the positive impact of oil price returns, the effect of exchange rate returns significantly varies across time and countries. Exchange rate parameters are found to be significant in only a few periods, however the magnitude of the coefficients is larger than those of oil price. Negative and significant coefficients are obtained for Brazil where the mean value of the parameter is -0.051 and it varies between - 0.374 (11 September 1998) and 0.453 (27 October 1997). India's oil-gas sector has been adversely affected by exchange rate hikes during the Asian crisis with negative and significant coefficients estimated from 1999 to mid 2001. It is also remarkable that negative and significant parameters are reported after 2017. In contrast, Indonesia's oil-gas sector has not been affected by exchange rate fluctuations during most of the analysis period, though it became the most adversely affected country attributable to the probable impact of the Asian financial crisis. In contrast with the other countries, the oil-gas returns of South Africa and Turkey are positively affected by exchange rate movements. Significant effects of exchange rate returns are reported for South Africa, especially between 1996 and 2003, with the effect of exchange rates reportedly peaking in early 1997. For Turkey, the exchange rate hike in 2018 is observed to have had a positive impact on the returns of its oil-gas sector. 


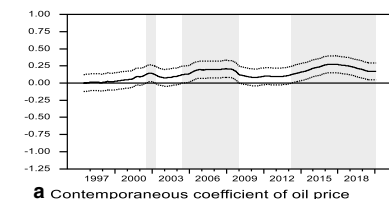

a contemporaneous coefficient of oil price a Brazil

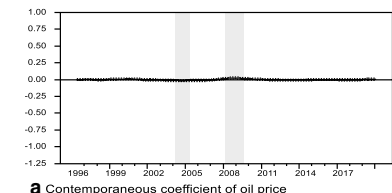

b India

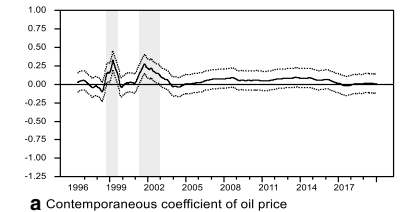

c Indonesia

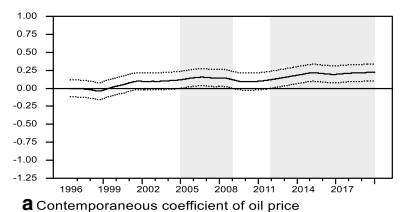

a contemporaneous coefficient of oil price

d South Africa

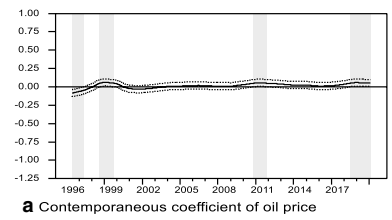

e Turkey

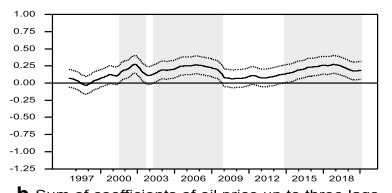

b sum of coefficients of oil price up to three lags

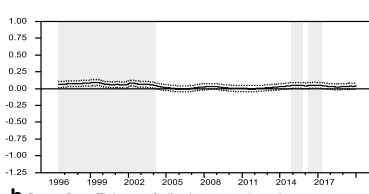

b sum of coefficients of oil price up to three lags

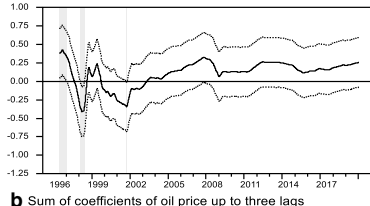

b sum of coefficients of oil price up to three lags

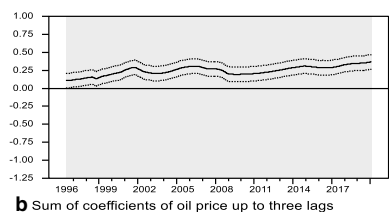

b Sum of coefficients of oil price up to three lags

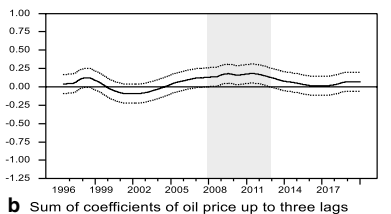

b Sum of coefficients of oil price up to three lags
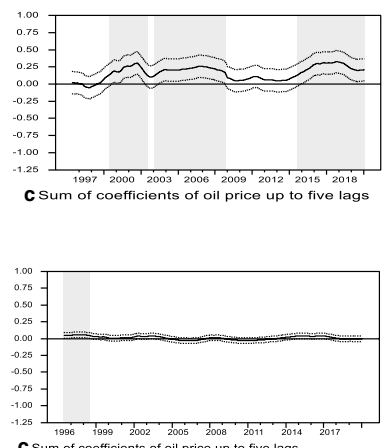

C Sum of coefficients of oil price up to five lags

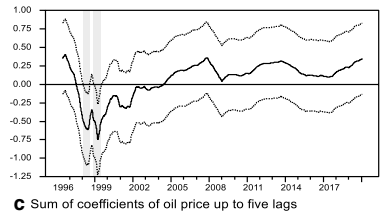

C Sum of coefficients of oil price up to five lags

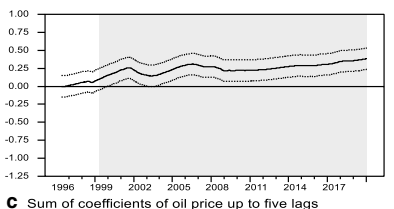

C Sum of coefficients of oil price up to five lags

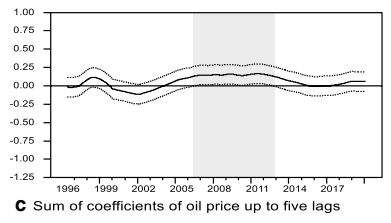

Fig. 2 Time-varying oil price parameters

\section{Conclusion}

This study aims to investigate the effects of oil price exposure on the oil-gas sectors of the fragile five countries based on a multi-factor asset pricing model. In particular, the impact of the market, oil prices, and exchange rate returns on the asset-pricing behavior of the oil-gas sector has been examined with the Bai-and Perron (2003) structural breaks test and a state-space model time-varying parameter. The structural break tests support the necessity of a nonlinear specification by identifying at least one significant structural break for each country.

Next, the time-varying parameter estimates reveal that the risk of the oil and gas sector was higher than the overall market risk for all countries over the analysis period. This implies that investors should consider the risk levels of the oil and gas sector while constituting their portfolios. The evidence of high-risk factor is consistent with the studies of Sanusi and Ahmad (2016) and Shaeri et al. (2016). Our statespace model estimates further imply that oil prices have a positive and significant impact on the oil-gas sector of all countries except Indonesia, where the oil price 


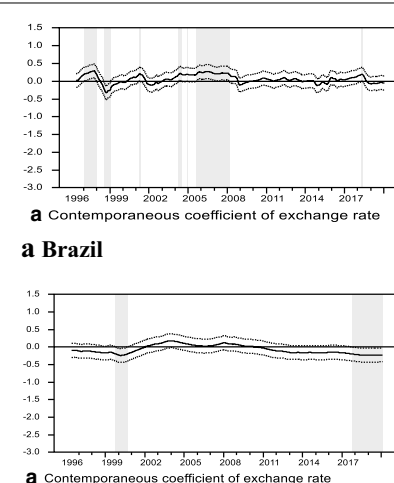

a contemporaneous coefficient of exchange rate

b India

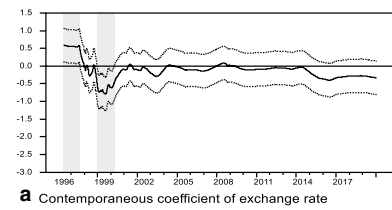

a Contemporaneous coofficient of exchange rate

c Indonesia

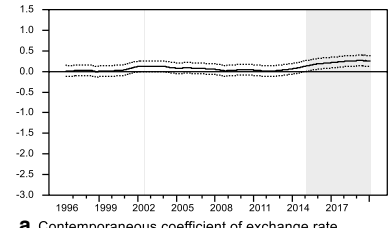

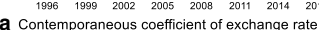

d South Africa

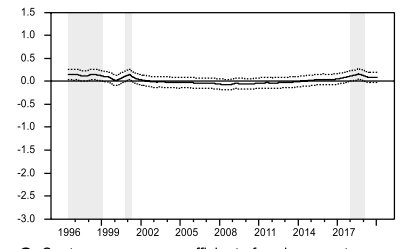

a Contemporaneous coefficient of exchange rate e Turkey
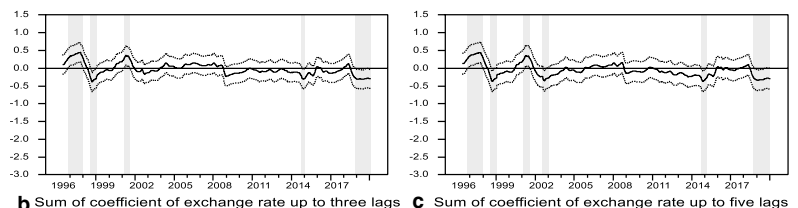

b Sum of coefficient of exchange rate up to three lags C Sum of coefficient of exchange rate up to five lags
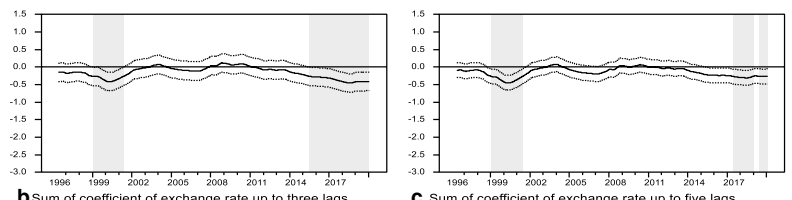

C Sum of coefficient of exchange rate up to five lags
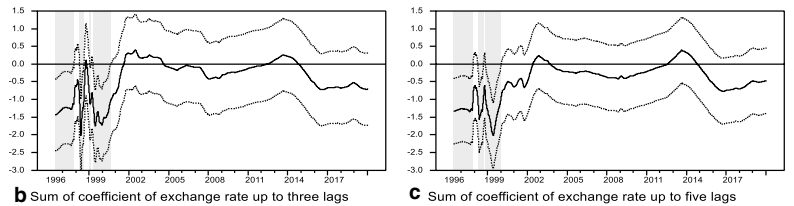

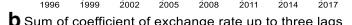

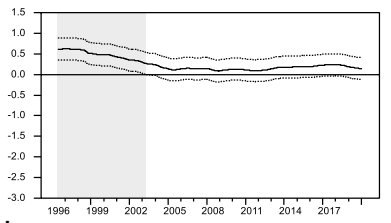

b sumb of coefficient of exchange rate up to three logs

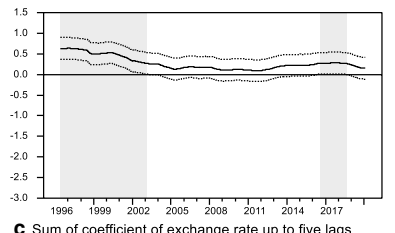

C Sum of coefficient of exchange rate up to five lags
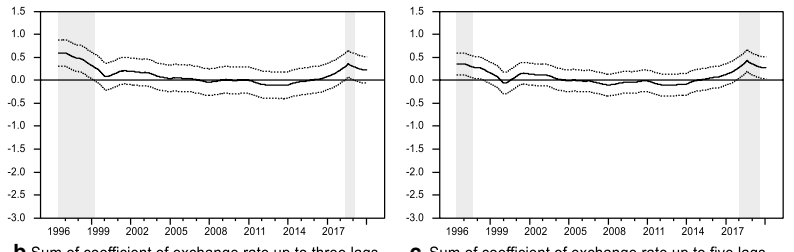

Fig. 3 Time-varying exchange rate parameters

coefficient is insignificant over the analysis period, though a negative and significant oil price coefficient is reported during the Asian financial crisis. Oil price has a more significant impact on the oil-gas sectors of South Africa and Brazil than those of other countries. The evidence of the positive and significant effect of oil prices is consistent with past studies including Sadorsky (2001), Ramos and Veiga (2011), ElSharif et al. (2005), and Diaz and de Gracia (2017). This indicates that the returns of the oil-gas sector depend crucially on oil price changes. Hence, oil price declines may induce uncertainty; at this point, oil price hedging can be beneficial in resolving this uncertainty. In addition, the fragile five countries can be good options for creating a diversified portfolio of stocks for investors.

Compared to oil prices, the sign and the magnitude of exchange rate parameters differ substantially across countries and over time. Fluctuations in exchange rates have a positive and significant impact on South African and Turkish oil-gas sectors, whereas the oil-gas 
Table 3 Descriptive properties of the time-varying parameters

\begin{tabular}{|c|c|c|c|c|c|c|}
\hline & Mean & SE & Minimum & & Maximum & \\
\hline \multicolumn{7}{|c|}{ Brazil } \\
\hline$\beta_{m, t}$ & 1.061 & 0.372 & 0.398 & 24/09/1998 & 1.853 & $15 / 04 / 2015$ \\
\hline$\beta_{\circ \mathrm{oil}, t}$ & 0.163 & 0.099 & -0.052 & 13/11/1997 & 0.327 & $01 / 11 / 2017$ \\
\hline $\begin{array}{l}\beta_{e r, t} \\
\text { India }\end{array}$ & -0.051 & 0.176 & -0.374 & $11 / 09 / 1998$ & 0.453 & 27/10/1997 \\
\hline$\beta_{m, t}$ & 0.889 & 0.190 & 0.495 & $11 / 02 / 2000$ & 1.122 & $23 / 01 / 2004$ \\
\hline$\beta_{o \mathrm{oil}, t}$ & 0.010 & 0.025 & -0.033 & $17 / 05 / 2006$ & 0.058 & 19/06/1997 \\
\hline $\begin{array}{l}\beta_{e r, t} \\
\text { Indor }\end{array}$ & -0.141 & 0.128 & -0.451 & 03/04/2000 & 0.075 & $02 / 01 / 2004$ \\
\hline$\beta_{m, t}$ & 0.976 & 0.348 & 0.338 & $05 / 11 / 2002$ & 1.837 & 27/10/1999 \\
\hline$\beta_{\text {oil }, t}$ & 0.069 & 0.241 & -0.743 & 01/04/1999 & 0.406 & 05/09/1996 \\
\hline \multicolumn{7}{|c|}{ South Africa } \\
\hline$\beta_{m, t}$ & 1.108 & 0.109 & 0.884 & 23/03/2001 & 1.385 & 10/09/1998 \\
\hline$\beta_{\text {oil }, t}$ & 0.227 & 0.090 & -0.002 & 07/06/1996 & 0.384 & $17 / 01 / 2020$ \\
\hline $\begin{array}{l}\beta_{e r, t} \\
\text { Turke }\end{array}$ & 0.273 & 0.159 & 0.090 & 26/09/2011 & 0.635 & 03/02/1997 \\
\hline$\beta_{m, t}$ & 0.873 & 0.098 & 0.750 & $25 / 03 / 2010$ & 1.219 & 07/06/1996 \\
\hline$\beta_{\text {oil }, t}$ & 0.054 & 0.081 & -0.114 & 08/02/2002 & 0.167 & 03/08/2011 \\
\hline$\beta_{e r, t}$ & 0.069 & 0.143 & -0.107 & $21 / 01 / 2008$ & 0.438 & $13 / 08 / 2018$ \\
\hline
\end{tabular}

sectors of Brazil, India, and Indonesia have been negatively affected by exchange rate fluctuations especially during the Asian financial crisis. This finding is consistent with the studies of Sadorsky (2001) and El-Sharif et al. (2005). In other words, exposure to exchange rate risks is still the case for these countries. The estimation results also provide that some of the fragile five countries (i.e., South Africa and Brazil) are more prone to changes in oil prices or exchange rates (i.e., South Africa and Turkey). Accordingly, exchange rate and oil price fluctuations should be considered by investors in making their investment decisions. Furthermore, in order to reduce the risk of the oil-gas sector, policy makers should also implement efficient policies aimed at stabilizing the volatility of exchange rates.

Due to data availability, we haven't taken into account the new fragile countries, i.e. Mexico and Colombia. Nevertheless, the results of the study highlight two main directions for future research. First, the impact of oil prices on the other industries associated with the oil-gas industry may be further investigated using the time-varying methodology. Second, the time-varying relationship between oil prices on the oil-gas sector of the countries may also suggest the possible asymmetric effects of oil prices that can be elaborated with asymmetric empirical methodologies, such as double threshold GARCH models by Yang and Chang (2008) and Elyasiani et al. (2013) or Threshold VAR model proposed by Huang et al (2005). Third, when the required data becomes available, the study can be repeated for the current fragile five economies oil-gas sector stock returns Tables 4, 5 and Figs. 4, 5, 6, 7, 8.

\section{Appendix}

See Tables 4, 5 and Figs. 4, 5, 6, 7, 8. 


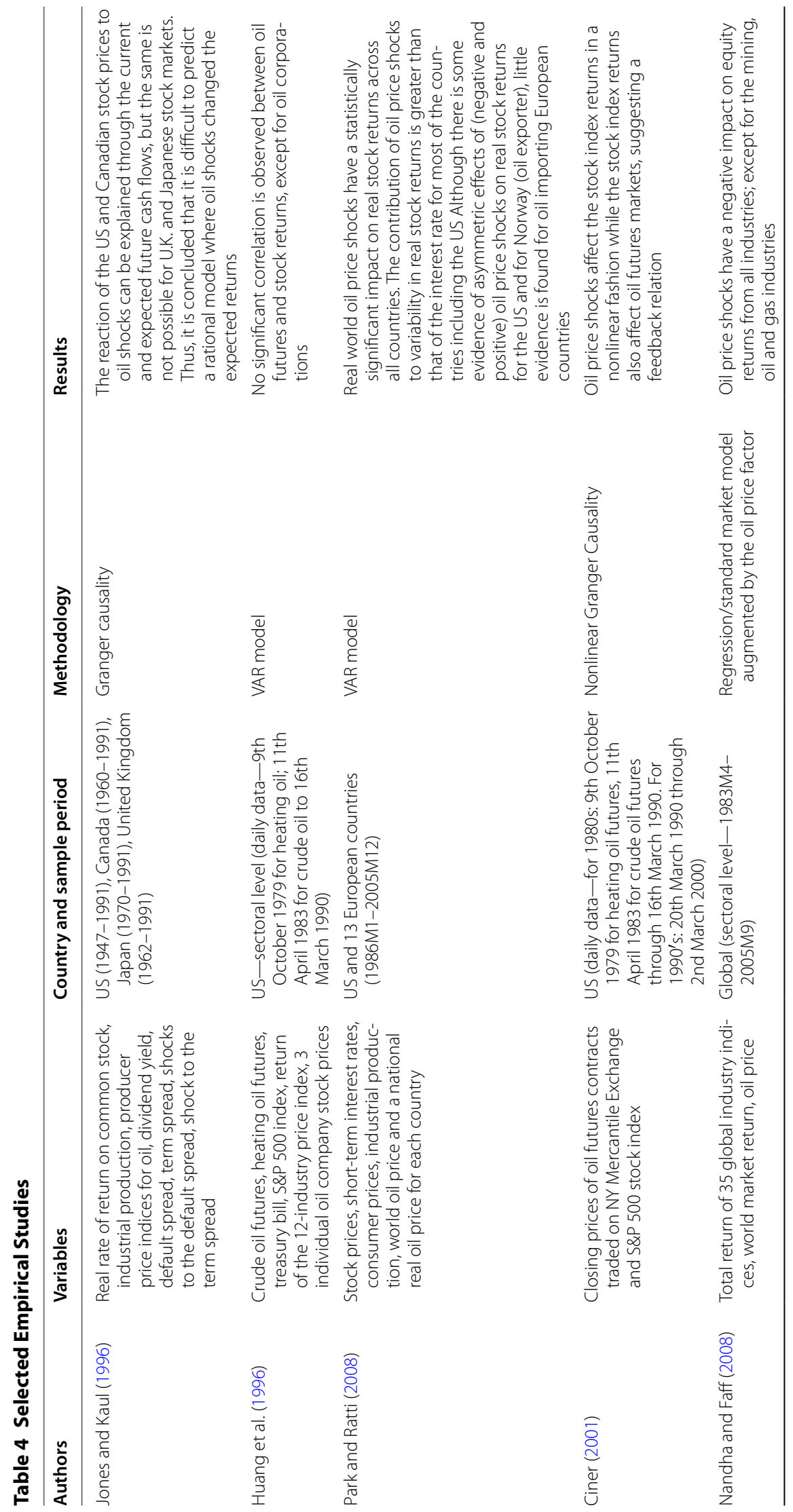




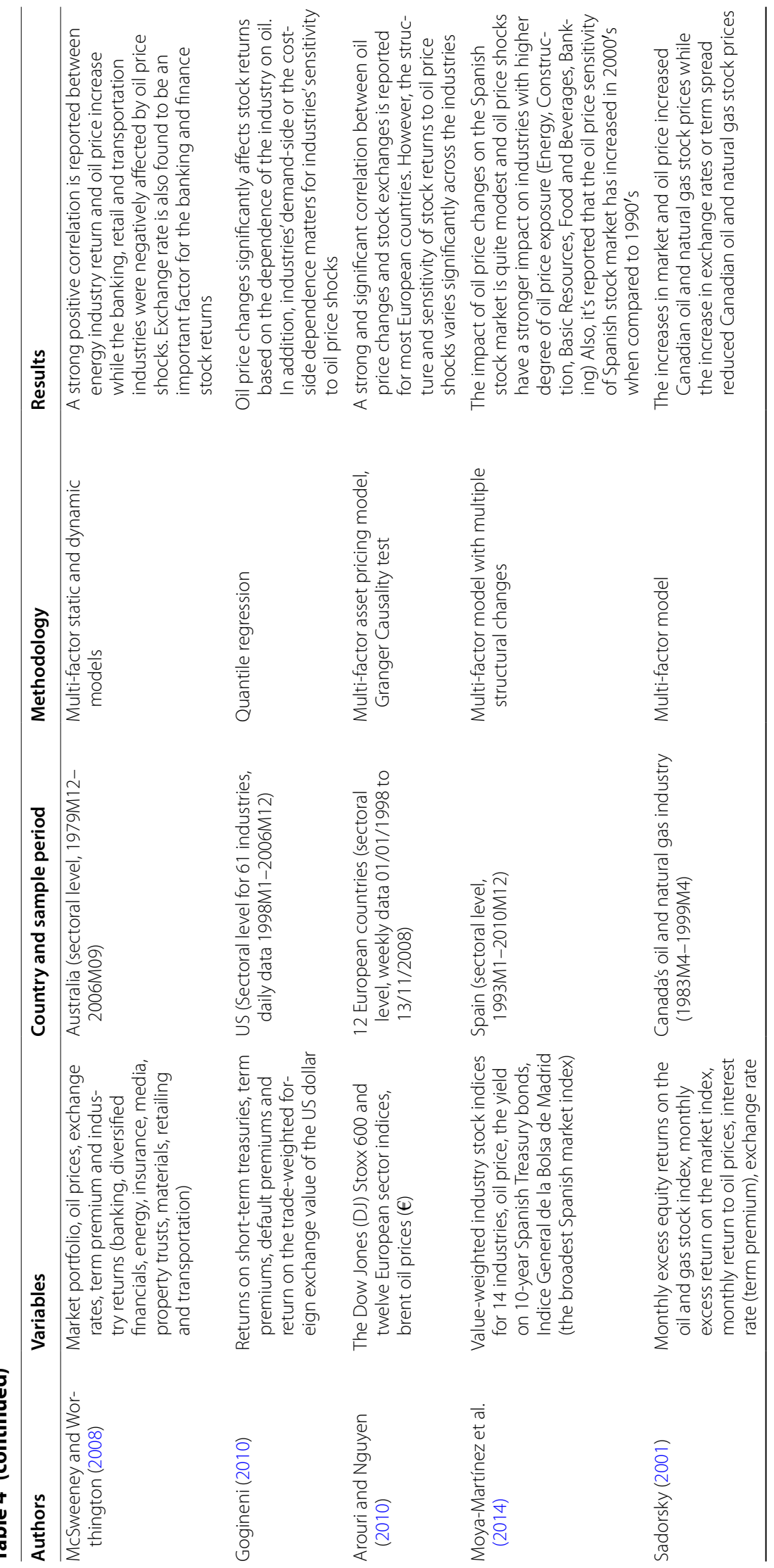




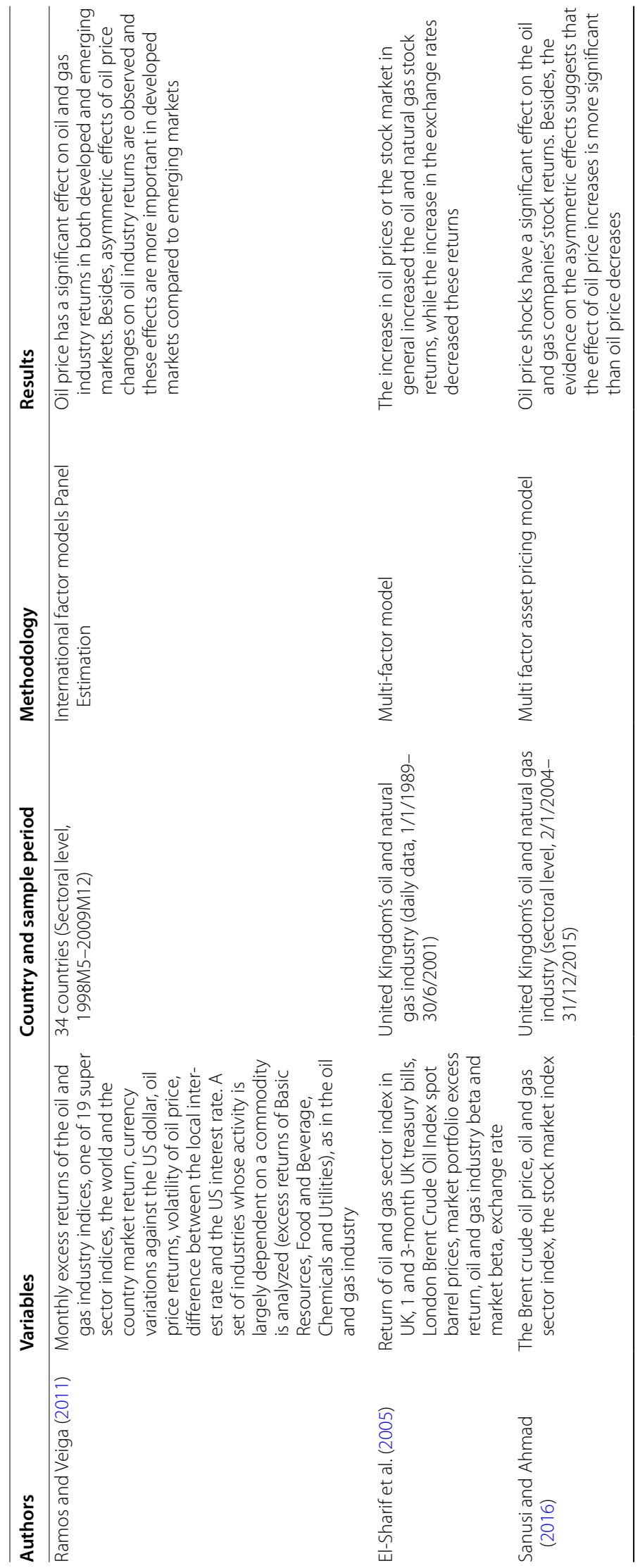


Table 5 Crude oil and natural gas production and trade. Source: International Energy Agency

\begin{tabular}{|c|c|c|c|c|c|c|c|c|c|}
\hline & 2010 & 2011 & 2012 & 2013 & 2014 & 2015 & 2016 & 2017 & $\begin{array}{l}\text { \%of total } \\
\text { in } 2017\end{array}$ \\
\hline \multicolumn{10}{|c|}{ Crude oil and NGL production (kt, kbbl/day) } \\
\hline Brazil & 130,994 & 130,183 & 128,766 & 129,657 & 142,579 & 153,717 & 156,381 & 162,270 & 3.6 \\
\hline India & 42,316 & 43,120 & 42,729 & 42,506 & 41,850 & 41,628 & 41,318 & 40,965 & 0.9 \\
\hline $\begin{array}{l}\text { Indone- } \\
\text { sia }\end{array}$ & 48,230 & 46,896 & 45,674 & 44,015 & 43,600 & 41,157 & 45,084 & 43,123 & 1.0 \\
\hline $\begin{array}{l}\text { South } \\
\text { Africa }\end{array}$ & 4496 & 5320 & 5100 & 5272 & 5375 & 5724 & 5811 & 5370 & 0.1 \\
\hline Turkey & 2515 & 2390 & 2364 & 2635 & 2758 & 3069 & 3171 & 3190 & 0.1 \\
\hline World & $4,091,976$ & $4,141,378$ & $4,232,049$ & $4,251,586$ & $4,345,515$ & $4,450,098$ & $4,511,859$ & $4,516,240$ & 100.0 \\
\hline \multicolumn{10}{|c|}{ Crude oil and NGL exports (kt, kbbl/day) } \\
\hline Brazil & 32,028 & 30,660 & 27,051 & 20,142 & 26,318 & 37,366 & 42,976 & 52,854 & 2.3 \\
\hline India & 0 & 0 & 0 & 0 & 0 & 0 & 0 & 0 & 0.0 \\
\hline $\begin{array}{l}\text { Indone- } \\
\text { sia }\end{array}$ & 15,629 & 17,237 & 15,319 & 15,588 & 14,599 & 15,254 & 16,691 & 13,672 & 0.6 \\
\hline $\begin{array}{l}\text { South } \\
\text { Africa }\end{array}$ & 1 & 0 & 0 & 0 & 0 & 0 & 0 & 0 & 0.0 \\
\hline Turkey & 0 & 0 & 370 & 206 & 400 & 418 & 649 & 515 & 0.0 \\
\hline World & $2,123,193$ & $2,149,226$ & $2,170,274$ & $2,147,012$ & $2,107,153$ & $2,211,914$ & $2,305,911$ & $2,331,794$ & 100.0 \\
\hline \multicolumn{10}{|c|}{ Crude oil and NGL imports (kt, kbbl/day) } \\
\hline Brazil & 17,182 & 16,831 & 17,495 & 20,006 & 17,757 & 15,100 & 7856 & 7348 & 0.3 \\
\hline India & 163,595 & 171,729 & 184,795 & 189,238 & 189,435 & 202,850 & 213,932 & 220,434 & 9.1 \\
\hline $\begin{array}{l}\text { Indone- } \\
\text { sia }\end{array}$ & 19,249 & 19,136 & 19,519 & 23,052 & 24,621 & 24,838 & 25,286 & 25,944 & 1.1 \\
\hline $\begin{array}{l}\text { South } \\
\text { Africa }\end{array}$ & 19,254 & 20,725 & 18,940 & 18,658 & 21,293 & 17,973 & 18,075 & 17,236 & 0.7 \\
\hline Turkey & 16,954 & 18,092 & 19,607 & 18,661 & 17,567 & 25,160 & 25,067 & 25,887 & 1.1 \\
\hline World & $2,237,625$ & $2,239,502$ & $2,249,135$ & $2,201,515$ & $2,182,181$ & $2,272,201$ & $2,341,961$ & $2,414,278$ & 100.0 \\
\hline \multicolumn{10}{|c|}{ Oil products imports (kt, kbbl/day) } \\
\hline Brazil & 21,891 & 24,287 & 24,203 & 23,410 & 24,724 & 21,247 & 22,069 & 27,665 & 2.1 \\
\hline India & 17,380 & 15,850 & 16,356 & 16,696 & 21,302 & 29,454 & 36,288 & 35,892 & 2.7 \\
\hline $\begin{array}{l}\text { Indone- } \\
\text { sia }\end{array}$ & 20,946 & 23,342 & 27,213 & 27,999 & 28,615 & 24,944 & 21,950 & 26,390 & 2.0 \\
\hline $\begin{array}{l}\text { South } \\
\text { Africa }\end{array}$ & 6630 & 8098 & 7414 & 7969 & 7733 & 9508 & 7298 & 9587 & 0.7 \\
\hline Turkey & 18,343 & 17,989 & 20,197 & 21,413 & 22,358 & 23,315 & 24,669 & 26,417 & 2.0 \\
\hline World & $1,094,257$ & $1,117,794$ & $1,129,594$ & $1,169,353$ & $1,182,644$ & $1,243,739$ & $1,304,653$ & $1,338,475$ & 100.0 \\
\hline \multicolumn{10}{|c|}{ Oil products exports (kt, kbbl/day) } \\
\hline Brazil & 6764 & 6816 & 6580 & 7363 & 6960 & 6216 & 5818 & 6137 & 0.4 \\
\hline India & 59,077 & 63,620 & 65,668 & 70,015 & 66,918 & 63,445 & 68,528 & 69,710 & 4.8 \\
\hline $\begin{array}{l}\text { Indone- } \\
\text { sia }\end{array}$ & 5381 & 5123 & 4292 & 4676 & 5250 & 4297 & 4052 & 3686 & 0.3 \\
\hline $\begin{array}{l}\text { South } \\
\text { Africa }\end{array}$ & 2235 & 2024 & 2768 & 3493 & 3245 & 4338 & 4018 & 3896 & 0.3 \\
\hline Turkey & 6357 & 7365 & 7256 & 7155 & 6551 & 7170 & 5840 & 6245 & 0.4 \\
\hline World & $1,144,647$ & $1,202,916$ & $1,224,435$ & $1,250,565$ & $1,276,067$ & $1,359,089$ & $1,411,280$ & $1,451,852$ & 100.0 \\
\hline
\end{tabular}

Kt kilotonnes, kbbl/day kilobarrels per day 

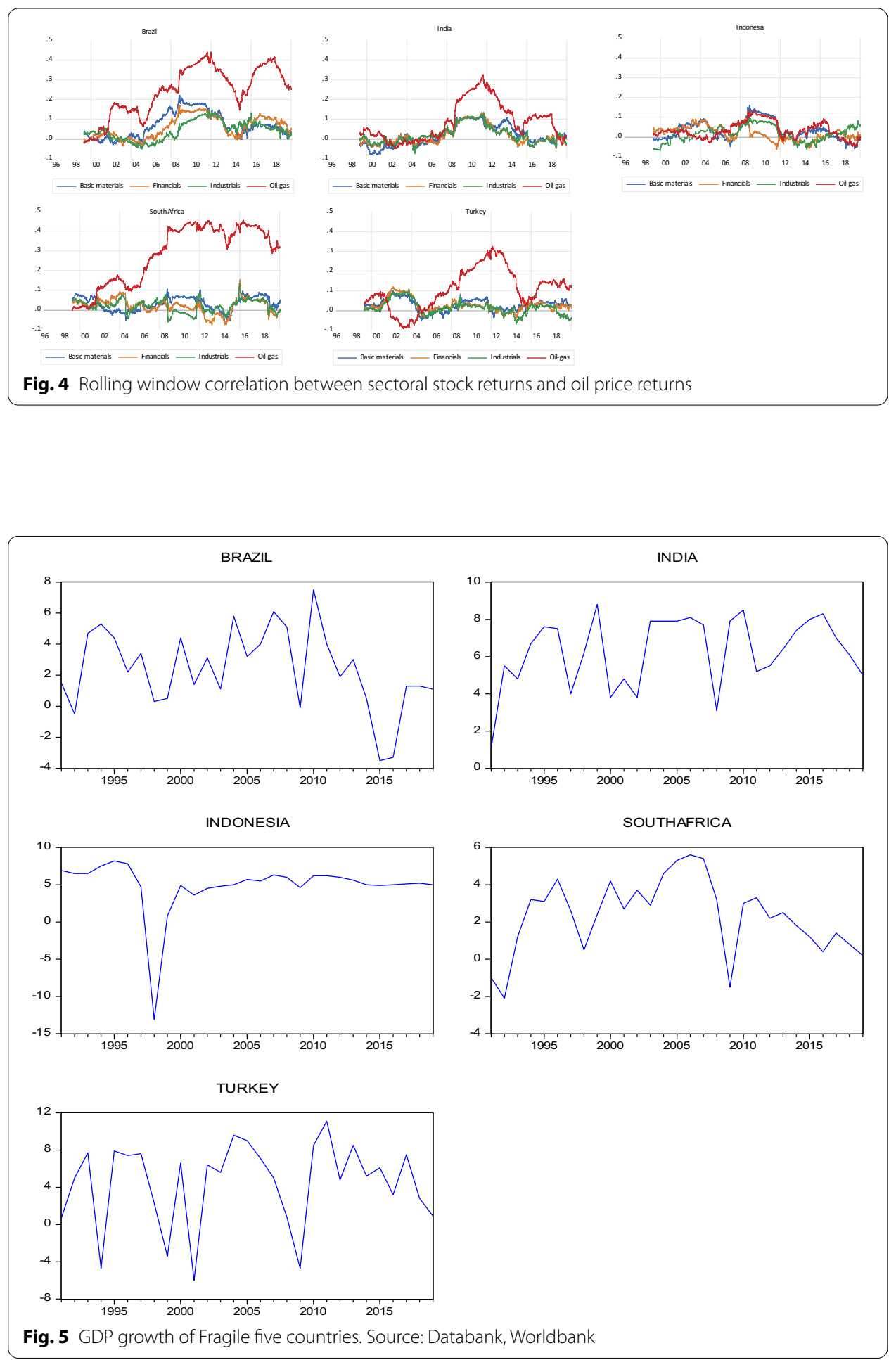

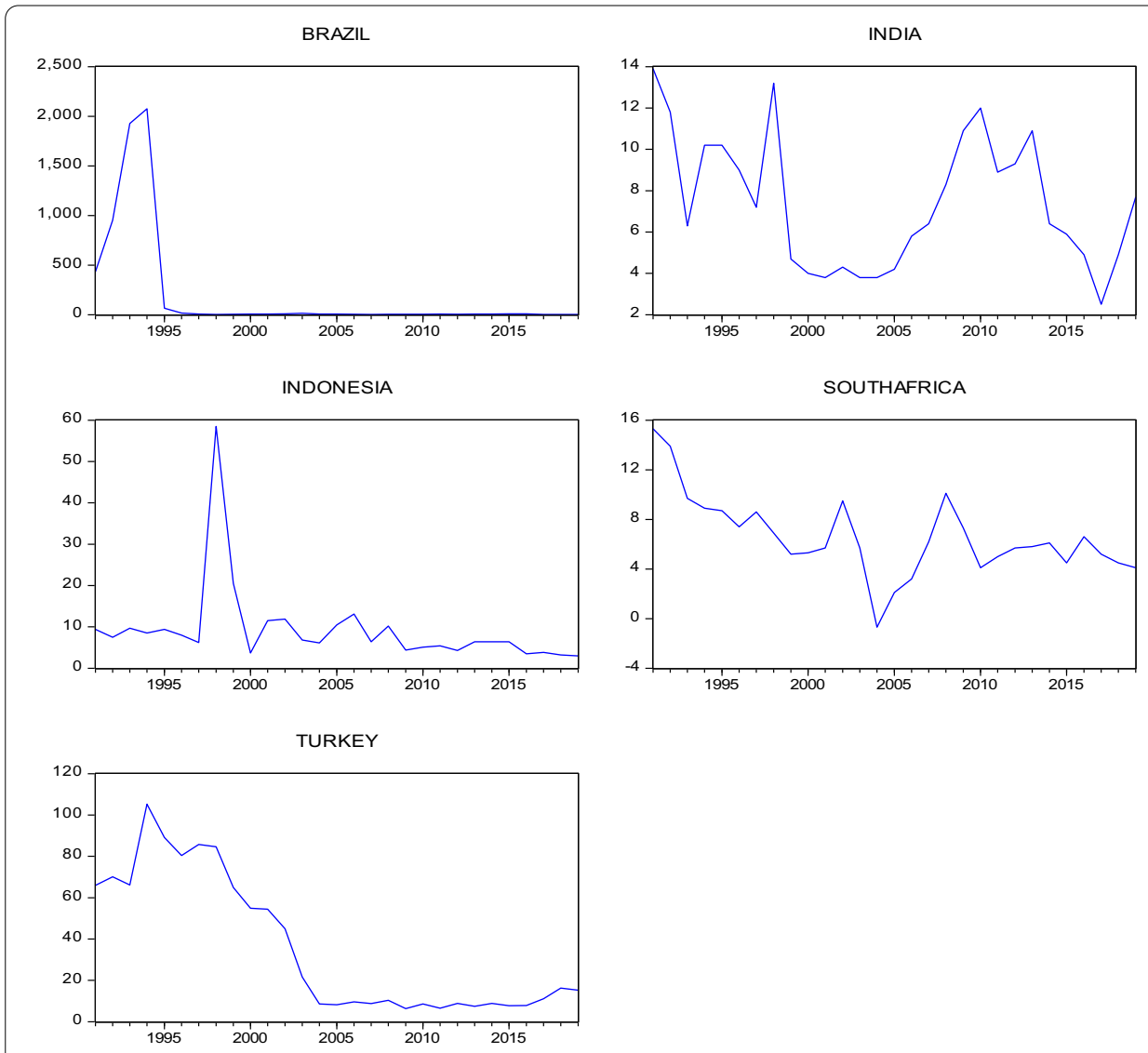

Fig. 6 Consumer price inflation. Source: Databank, Worldbank 


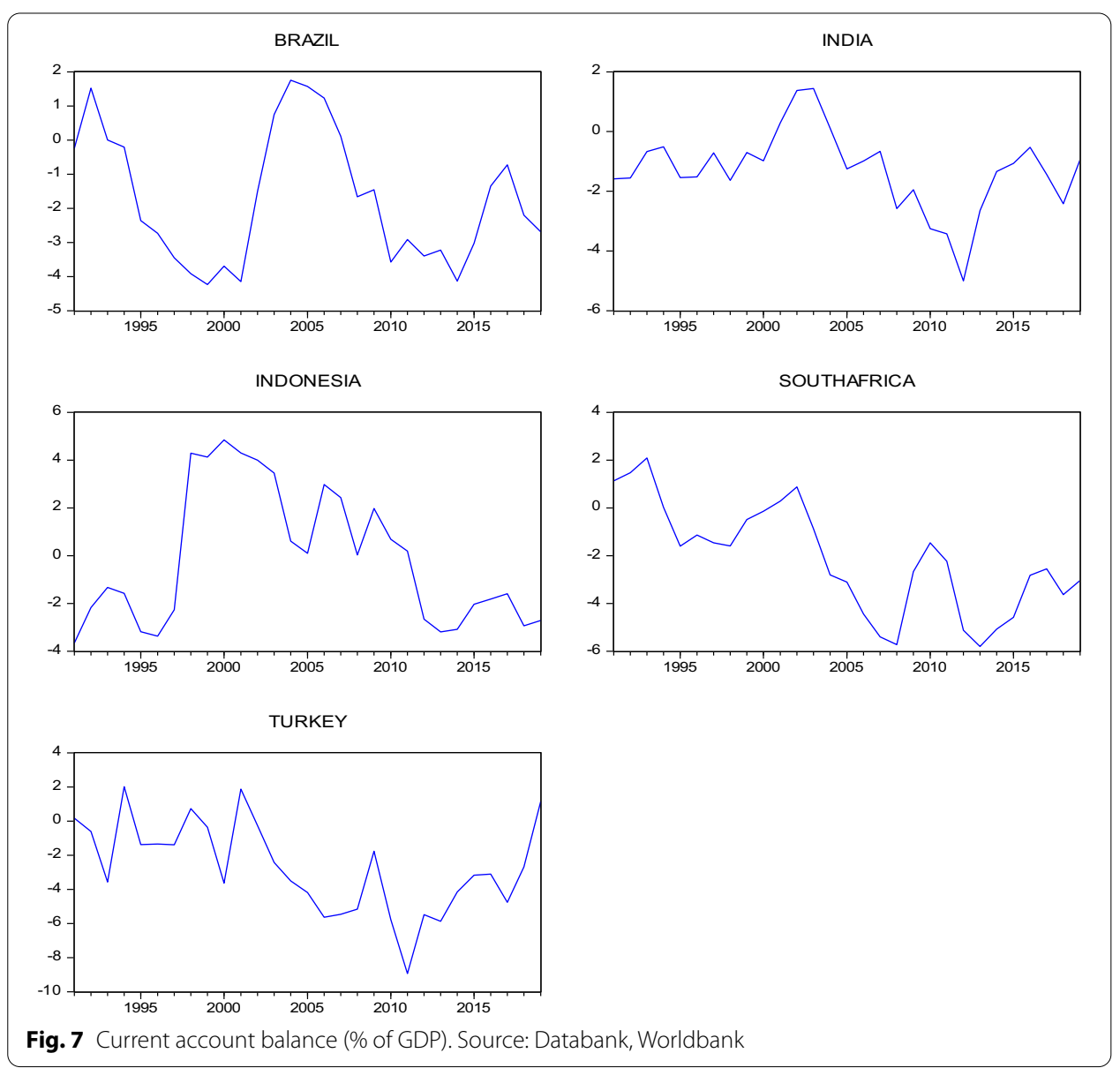


BRAZIL

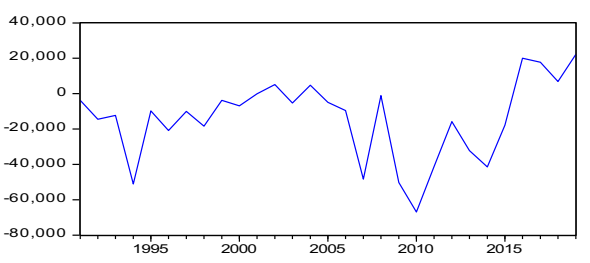

INDONESIA

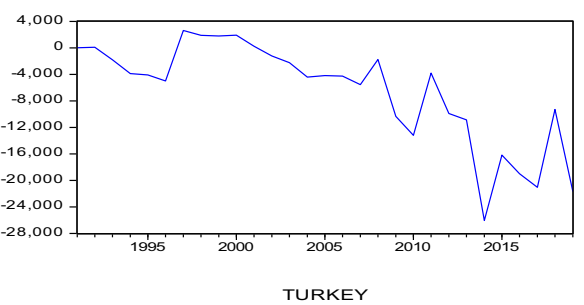

TURKEY

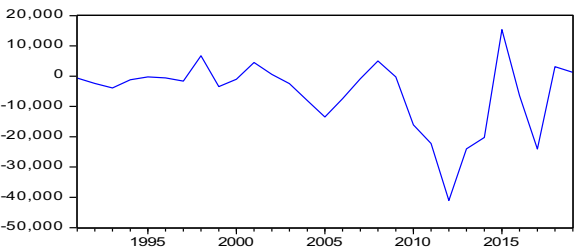

INDIA

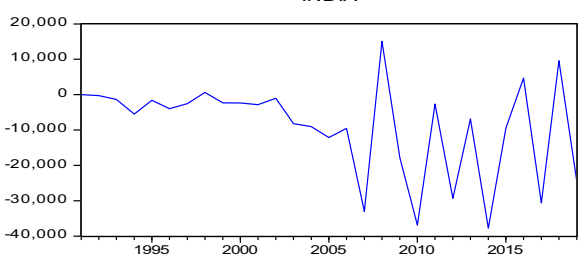

SOUTHAFRICA

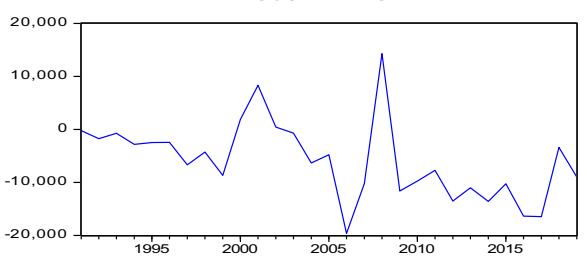

Fig. 8 Net portfolio investment (BoP, current million US\$). Source: Databank, Worldbank

Received: 23 April 2020 Accepted: 22 December 2020

Published online: 05 January 2021

\section{References}

Aloui C, Nguyen DK, Njeh H (2012) Assessing the impacts of oil price fluctuations on stock returns in emerging markets. Econ Model 29:2686-2695

Apergis N, Miller SM (2009) Do structural oil-market shocks affect stock prices? Energy Econ 31:569-575

Arouri ME, Nguyen DK (2010) Oil prices, stock markets and portfolio investment: Evidence from sector analysis in Europe over the last decade. Energy Policy 38:4528-4539

Arouri ME, Rault C (2011) Oil prices and stock markets in GCC countries: empirical evidence from panel analysis. Int J Finance Econ 17(3):242-253

Bai J, Perron P (1998) Estimating and testing linear models with multiple structural changes. Econometrica 66:47-78 Bai J, Perron P (2003) Critical values for multiple structural change tests. Econ J 1:1-7

BP (2020) Retrieved 08 26, 2020, from https://www.bp.com/content/dam/bp/business-sites/en/global/corporate/pdfs/ energy-economics/statistical-review/bp-stats-review-2020-full-report.pdf

Broadstock DC, Cao H, Zhang D (2012) Oil shocks and their impact on energy related stocks in China. Energy Econ 34:1888-1895

Choudhry T, Wu H (2008) Forecasting ability of GARCH vs. Kalman filter method: Evidence from daily UK time-varying beta. J Forecast 27:670-689

Ciner C (2001) Energy shocks and financial markets: nonlinear linkage. Stud Nonlinear Dyn Econom 5:203-212

Commandeur JF, Koopman SJ (2007) An introduction to state space time series analysis. Oxford University Press, London Diaz EM, Gracia FP (2017) Oil price shocks and stock returns of oil and gas corporations. Finance Res Lett 20:75-80

El-Sharif IDBBB, Nixon B, Russell A (2005) Evidence on the nature and extent of the relationship between oil prices and equity values in the UK. Energy Econ 27:819-830

Elyasiani E, Mansur I, Odusami B (2011) Oil price shocks and industry stock returns. Energy Econ 33:966-974

Elyasiani E, Mansur I, Odusami B (2013) Sectoral stock return sensitivity to oil price changes: a double-threshold FIGARCH model. Quant Finance 13(4):593-612

Gogineni S (2010) Oil and the stock market: an industry level analysis. Financ Rev 45:995-1010

Hammoudeh S, Choi K (2006) Behavior of GCC stock markets and impacts of US oil and financial markets. Res Int Bus Finance 2006:22-44

Huang RD, Masulis RW, Stoll HR (1996) Energy shocks and financial markets. J Fut Mark 16(1):1-27

Huang B-N, Hwang MJ, Peng H-P (2005) The asymmetry of the impact of oil price shocks on economic activities: an application of the multivariate threshold model. Energy Econ 27:455-476 
Huang S, An H, Gao X, Sun X (2017) Do oil price asymmetric effects on the stock market persist in multiple time horizons? Appl Energy 185:1799-1808

Inchauspe J, Ripple RD, Trück S (2015) The dynamics of returns on renewable energy companies: a state-space approach. Energy Econ 48:325-335

Jebran K, Chen S, Saeed G, Zeb A (2017) Dynamics of oil price shocks and stock market behavior in Pakistan: evidence from the 2007 financial crisis period. Financ Innov 3(1):2

Jensen MC (1968) The performance of mutual funds in the period 1945-1964. J Finance 23(2):389-416

Jiménez-Rodríguez R (2015) Oil price shocks and stock markets: testing for non-linearity. Empir Econ 48:1079-1102

Jones CM, Kaul G (1996) Oil and the stock markets. J Finance 51(2):463-491

Joo YC, Park SY (2017) Oil prices and stock markets: does the effect of uncertainty change over time? Energy Econ 61:42-51

Kalman RE (1960) A new approach to linear filtering and prediction problems. J Basic Eng 82:35-45

Kang W, Ratti RA, Vespignani J (2016) The impact of oil price shocks on the US stock market: a note on the roles of US and non-US oil production. Econ Lett 145:176-181

Karlsson HK, Hacker RS (2013) Time-varying betas of sectoral returns to market returns and exchange rate movements. Appl Financ Econ 23(14):1155-1168

Kilian L, Park C (2009) The impact of oil price shocks on the US stock market. Int Econ Rev 50(4):1267-1287

Kim C-K, Nelson CR (1999) Has The US Economy Become More Stable? A Bayesian approach based on a Markov-switching model of the business cycle. Rev Econ Stat 81(4):608-616

Lee C-C, Zeng J-H (2011) The impact of oil price shocks on stock market activities: asymmetric effect with quantile regression. Math Comput Simul 81:1910-1920

Lintner J (1965) The valuation of risk assets and the selection of risky investments in stock portfolios and capital budgets. Rev Econ Stat 47(1):13-37

Liu J, Wu S, Zidek J (1997) On segmented multivariate regression. Stat Sin 1997:497-525

Maghyereh A (2004) Oil price shocks and emerging stock markets: a generalized VAR approach. Int J Appl Econom Quant Stud 2004:1-2

Markowitz H (1959) Portfolio selection: efficient diversification of investments. Wiley, New York

McSweeney EJ, Worthington AC (2008) A comparative analysis of oil as a risk factor in Australian industry stock returns, 1980-2006. Stud Econ Finance 25(2):131-145

Miller JI, Ratti RA (2009) Crude oil and stock markets: stability, instability, and bubbles. Energy Econ 31:559-568

Morgan Stanley (2013) Retrieved 08 26, 2020, from http://graphics8.nytimes.com/packages/pdf/business/Morga nStanleyFragileFive.pdf.

Moya-Martínez P, Ferrer-Lapeña R, Escribano-Sotos F (2014) Oil price risk in the Spanish stock market: an industry perspective. Econ Model 37:280-290

Nandha M, Faff R (2008) Does oil move equity prices? A global view. Energy Econ 30:986-997

Nandha M, Hammoudeh S (2007) Systematic risk, and oil price and exchange rate sensitivities in Asia-Pacific stock markets. Res Int Bus Finance 21:326-341

Narayan PK, Sharma SS (2011) New evidence on oil price and firm returns. J Bank Finance 35:3253-3262

Nasir M, Naidoo L, Shahbaz M, Amoo N (2018) Implications of oil prices shocks for the major emerging economies: a comparative analysis of BRICS. Energy Econ 76:76-88

Park J, Ratti RA (2008) Oil price shocks and stock markets in the US and 13 European countries. Energy Econ 30:2587-2608

Ramos SB, Veiga H (2011) Risk factors in oil and gas industry returns: international evidence. Energy Econ 33:525-542

Roubaud D, Arouri M (2018) Oil prices, exchange rates and stock markets under uncertainty and regime-switching. Finance Res Lett 27:28-33

Sadorsky P (2001) Risk factors in stock returns of Canadian oil and gas companies. Energy Econ 23:17-28

Sanusi MS, Ahmad F (2016) Modelling oil and gas stock returns using multi factor asset pricing model including oil price exposure. Finance Res Lett 18:89-99

Shaeri K, Adaoglu C, Katircioglu S (2016) Oil price risk exposure: a comparison of financial and non-financial subsectors. Energy 109:712-723

Sharpe WF (1964) Capital asset prices: a theory of market equilibrium under conditions of risk. J Finance 19(3):425-442

Uzo-Peters A, Laniran T, Adenikinju A (2018) Brent prices and oil stock behaviors: evidence from Nigarian listed oil stocks. Financ Innov 4:8

Wang Y, Wu C, Yang L (2013) Oil price shocks and stock market activities: evidence from oil-importing and oil-exporting countries. J Compar Econ 41:1220-1239

Wen F, Xu L, Ouyang G, Kou G (2019) Retail investor attention and stock price crash risk: evidence from China. Int Rev Financial Anal 65:101376

Yang Y-L, Chang C-L (2008) A double-threshold GARCH model of stock market and currency shocks on stock returns. Math Comput Simul 79:458-474

Zhang YJ, Fan Y, Tsai HT, Wei YM (2008) Spillover effect of US dollar exchange rate on oil prices. J Policy Model 30:973-991

Zhu H-M, Li S-F, Yu K (2011) Crude oil shocks and stock markets: a panel threshold cointegration approach. Energy Econ 33:987-994

\section{Publisher's Note}

Springer Nature remains neutral with regard to jurisdictional claims in published maps and institutional affiliations. 